\title{
Minimizing Distortion by Transient Thermal Tensioning and Its Effect on Fatigue Crack Growth Behavior of Flux Cored Arc Steel Weld Joints
}

\author{
N Subeki ${ }^{\# *^{1}}$, Jamasri ${ }^{\# 2}$, M.N. Ilman ${ }^{\# 3}$, P.T. Iswanto ${ }^{\# 4}$ \\ \#Department of Mechanical and Industrial Engineering, Universitas Gadjah Mada \\ J1. Grafika No. 2, Yogyakarta, 55281, Indonesia \\ 1) nursubeki@gmail.com \\ 2) jamasri_tmugm@ugm.ac.id \\ ${ }^{3)}$ Coresponding author: noer_ilman@ugm.ac.id \\ 4) priyotri@ugm.ac.id \\ * Department of Mechanical Engineering, University of Muhammadiyah Malang, \\ J1 Raya Tlogomas 246 Malang 65144, East Java, Indonesia
}

\begin{abstract}
The need for weight saving and low distortion in structural design such us ship and railway structures is accomplished by the use of welding as a joining technique. This is becouse welding process allows to join thin plates despite the use of thin section material often produces distortion which leads to loss of precision and even structural integrity. One of welding techniques which is widely used for joining steel construction is flux-cored arc welding (FCAW). The aim of this study is to control distortion and improve fatigue performance using transient thermal tensioning (TTT).

In this research, welding was conducted with and without TTT treatment. The secondary flame heating temperature for TTT treatments were $100{ }^{\circ} \mathrm{C}, 200{ }^{\circ} \mathrm{C}$, and $300{ }^{\circ} \mathrm{C}$ and during welding process the thermal cycles were measured using a data acquisition. After the welding process was completed, a sequence of an experiment was conducted including chemical, distortion measurement and fatigue crack propagation test. Results show that TTT treatment reduces distortion and improves fatigue crack growth performance with the optimum heating temperature is achieved at $200{ }^{\circ} \mathrm{C}$.
\end{abstract}

Keyword-Thin plate, FCAW weld, TTT weld treatment, distortion, and fatigue.

\section{INTRODUCTION}

To date a welding technique plays an important role in design and manufacturing process especially for reducing heavy products, and energy consumption savings [1]. The weld joints are used in pressure vessels, ship structures and offshore buildings. Factors affecting the quality of weld joints include welding technique, electrode, joint designs and weld thermal cycles [2]. Because weld joints are heated locally by the welding heat source, temperatures around the weld joints are not uniform, but they vary with the distance from the weld centerline. Combined effect of local heating and undesirable thermo-physical properties such as high coefficient of expansion and high thermal conductivity can cause buckling distortion and residual stress.

Comprehensive studies have been conducted to control buckling distortion and residual stress in thin plates either by post weld treatment or in-process welding. In-process welding includes preheating [3][4], static thermal tensioning [5][6][7] and the transient thermal tensioning [8][9][10][11]. Transient thermal tensioning is a technique for controlling the residual stress and distortion by applying secondary heating which moves together with the weld torch (heat source). The secondary heat sources are located at both sides of the weld well in front, beside and behind the weld torch.

One of the welding techniques that is widely used to join steel constructions is an arc welding with welding wire containing a flux known as flux-cored arc welding (FCAW). It is easy for operation and it can be operated continuously. The FCAW process involves wire filler which also acts as an consumable electrode and it is a feed continuously. As a result, welding can be performed semi-automatically, it is comfortable to operate and it has high reliability. FCAW is used for welding fillet lengthwise and for connecting the transverse done semi-automatically [12].

The number of distortion and residual stress actually can be predicted by welding simulation [13]. Problems that often arise in the weld joint are distortion and residual stress that influence dimensional precision, less of structural integrity and fatigue as reported by a number of researchers [4][6][7][8]. Additional works such as post weld heat treatment and welding repairs need to be done to correct distortions and reduce the residual stresses. This means that more time and production cost are required for these techniques. In process welding 
such as TTT treatment would be more effective since it is carried out during process hence no additional work is required after welding. Therefore, the present investigation is aimed to study distortion and residual stress, and its effect on fatigue crack propagation resistance.

\section{MATERIAL AND METHODS}

Materials used in this research were A36 Steel plates with the dimensions of $5 \times 120 \times 300 \mathrm{~mm}$. The steel plates have a yield stress of $248 \mathrm{MPa}$ and a maximum tensile stress of $400 \mathrm{MPa}$ with $20 \%$ in elongation. The filler metal used in this experiment was K-71T (AWS A5.20 / ASME SFA-5:20 E71T-1C) with a diameter of $1.2 \mathrm{~mm}$. The experiment set-up is shown in Fig. 1.

The welding parameters including voltage, current and heat input used were 40 volts, 210 Ampere and $2.184 \mathrm{~kJ} / \mathrm{mm}$ respectively. FCAW welding process was conducted by using welding speed of $3.846 \mathrm{~mm} / \mathrm{s}$. The secondary heating temperatures used were $100{ }^{\circ} \mathrm{C}, 200{ }^{\circ} \mathrm{C}$, and $300^{\circ} \mathrm{C}$. The thermal cycles were measured using thermocouples located at the distance of $10 \mathrm{~mm}, 35 \mathrm{~mm}, 55 \mathrm{~mm}$ and $80 \mathrm{~mm}$ from weld centerline.

After welding, distortion measurement was conducted with the dial indicator in longitudinal and transversal directions. Test on fatigue propagation rate was conducted with Servopulser machine. The specimen used was center crack tension (CCT) according to ASTM E 647-00 standard model. The frequency (f) and stress ratio (R) is maintained at $11 \mathrm{~Hz}$ and 0.1 .
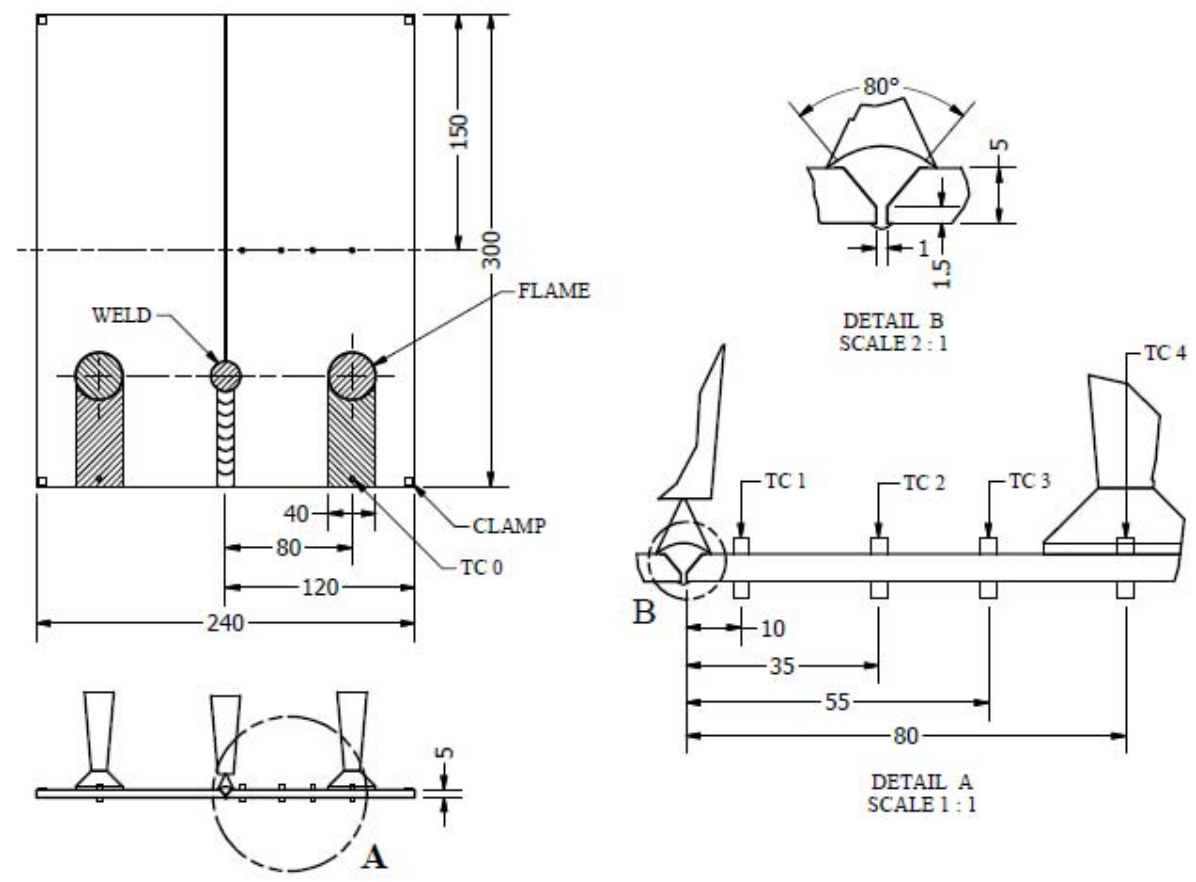

Fig. 1. Experimental setup of TTT treatment facilities for a FCAW welding process

\section{RESULTS AND DISCUSSION}

The chemical composition of both weld metal and base metal are shown in Table 1 . It can be seen that the amount of $\mathrm{C}$ in weld metal is low whereas the percentage of $\mathrm{Mn}$ is $1.583 \%$ and this is considered to be the optimum Mn content steel weld metal. This weld metal is known as C-Mn steel where its tensile strength and toughness are controlled by the $\mathrm{Mn} / \mathrm{C}$ ratio as reported by Surian, at al. [14]. Referring to Table 1 the percentage of $\mathrm{C}$ of weld metal is be lower with higher Mn content compared to the base metal.

TABLE 1. Chemical composition of base metal and weld metal (wt \%)

\begin{tabular}{|c|c|c|c|c|c|c|}
\hline Element & $\mathbf{C}$ & $\mathbf{M n}$ & $\mathbf{S i}$ & $\mathbf{P}$ & $\mathbf{S}$ & $\mathbf{C r}$ \\
\hline Weld metal & 0.080 & 1.583 & 0.736 & 0.005 & 0.009 & 0.028 \\
\hline Base metal & 0.125 & 0.471 & 0.249 & 0.015 & 0.011 & 0.020 \\
\hline
\end{tabular}


The weld thermal cycles under various secondary heating temperatures at $80 \mathrm{~mm}$ were measured by using thermocouple located in four points, namely TC1, TC2, TC3 and TC4 at the distance of $10 \mathrm{~mm}, 35 \mathrm{~mm}, 55 \mathrm{~mm}$ and $80 \mathrm{~mm}$ respectively as shown Figure 1. Figure 2 shows weld thermal cycles with and without TTT treatment. As shown in Figure $2 \mathrm{a}$ the temperatures of untreated welded plate are $782{ }^{\circ} \mathrm{C}, 302{ }^{\circ} \mathrm{C}, 180{ }^{\circ} \mathrm{C}$ and $143{ }^{\circ} \mathrm{C}$ of note is that the temperature distribution can affect distortion and residual stress whereas thermal cycles influence weld cooling rate which determine the mechanical properties of weld [15].

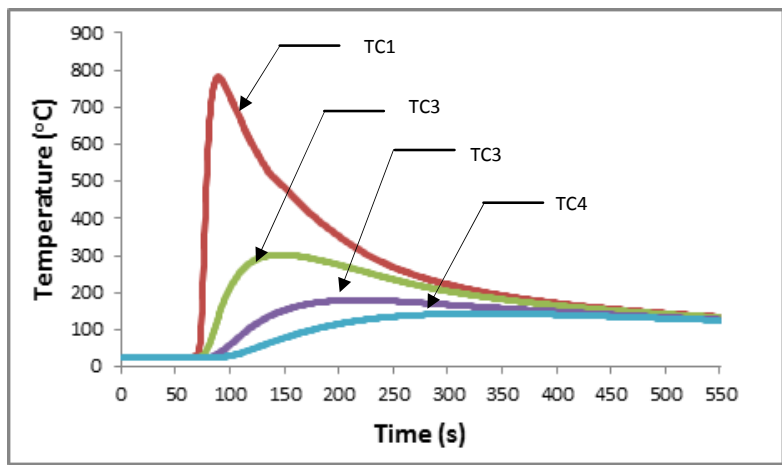

(a). As welded

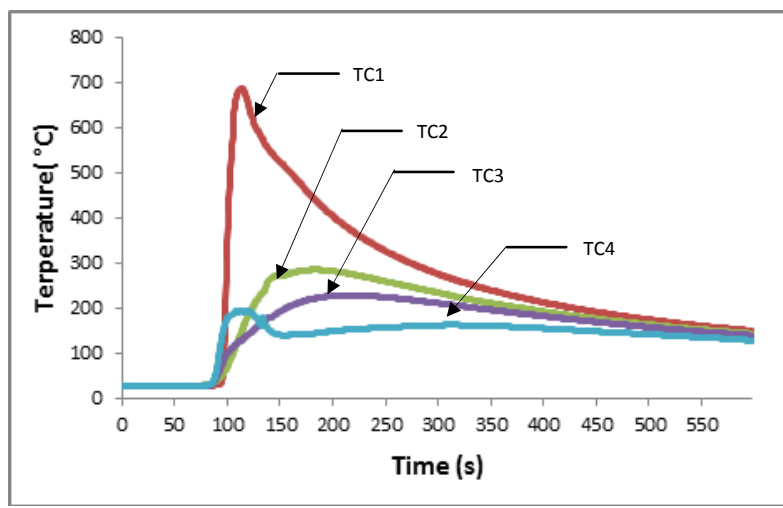

(c). TTT $200{ }^{\circ} \mathrm{C}$

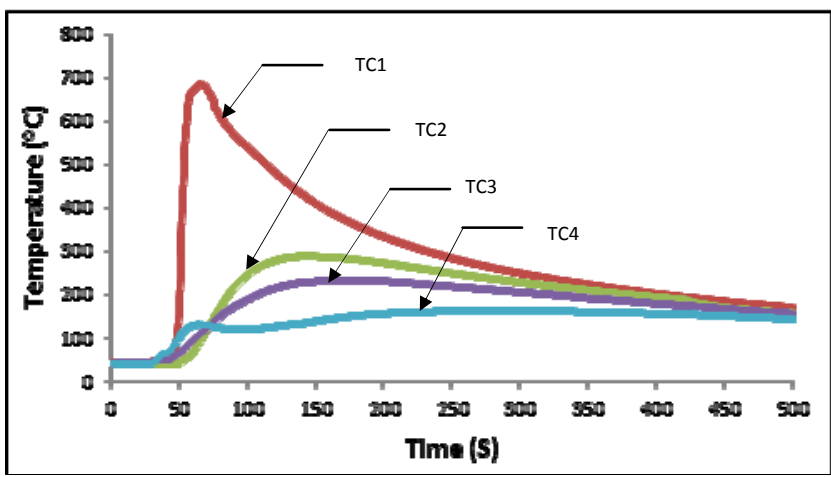

(b). $\operatorname{TTT} 100{ }^{\circ} \mathrm{C}$

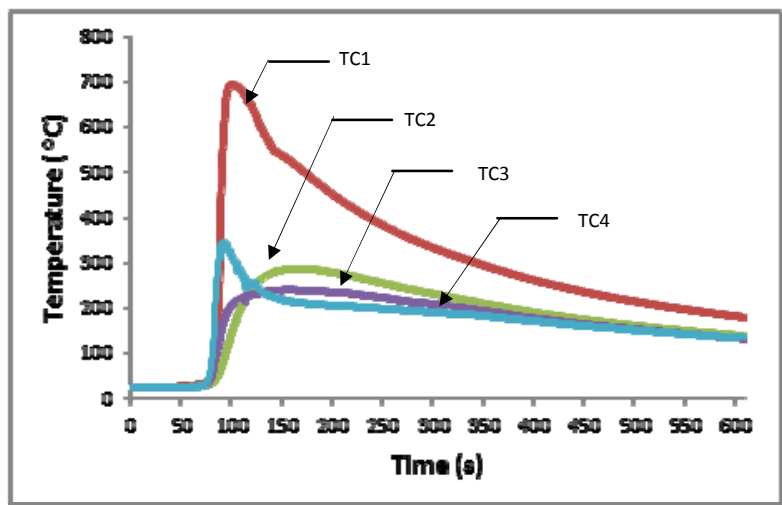

(d). $\operatorname{TTT} 300{ }^{\circ} \mathrm{C}$

Fig. 2. Result of temperature in (a) As welded, (b), (c), (d) TTT treatment condition with $100{ }^{\circ} \mathrm{C}, 200{ }^{\circ} \mathrm{C}, 300{ }^{\circ} \mathrm{C}$ heating temperature.

In TTT condition at heating temperature of $100{ }^{\circ} \mathrm{C}$ as shown in Fig. $2 \mathrm{~b}$, the peak temperature from the closest distance the weld centerline is $685{ }^{\circ} \mathrm{C}$, while increasing distance up to $35 \mathrm{~mm}$ from the weld centerline decreases temperature to $290{ }^{\circ} \mathrm{C}$. Further decrease in observed at the distance of $55 \mathrm{~mm}$ where the peak temperature at this position is $235{ }^{\circ} \mathrm{C}$ and finally at the distance of $80 \mathrm{~mm}$ the peak temperature is $166^{\circ} \mathrm{C}$. The effect of TTT on welded thermal cycles can be studied by comparing Fig. 2a-2d. It can be seen that temperature does not affect significantly the peak temperature of region near the weld area (TC1) but the effect of increasing TTT temperature as observed at the distance far from the weld TC2, TC3 and TC4 changes temperature distribution. These temperature changes resulted from TTT treatment are expected to generate thermal tension which help to reduce distortion and residual stress.

Results of 3D and 2D dimension curves of the welded plates prepared using the conventional welding and the TTT treatment can be seen in Fig. 3. As shown in Fig. 3 (a-d) the distortions for all welded plate specimens were measured along the longitudinal and transversal directions. The highest distortion in longitudinal and transverse direction are $10.56 \mathrm{~mm}$ and $5.8 \mathrm{~mm}$ respectively observed in as-welded condition as seen in Fig. 3 (a). TTT weld treatment could decrease distortion. These results are consistent with previous report which shows that distortion could be reduced by thermal tensioning [4]. In this research, the optimum TTT treatment occurs at temperature $200{ }^{\circ} \mathrm{C}$ marked by the lowest distortion. The results of measurements distortion at the edge of the welded plates along a longitudinal direction in Fig. 3 (e) shown the longitudinal distortions are seen to be concave with maximum distortions occur at the middle of the plates. At TTT temperature of $200{ }^{\circ} \mathrm{C}$ and $300{ }^{\circ} \mathrm{C}$, the longitudinal distortions are very low where their values at the middle part of the welded plate length are $-6.16 \mathrm{~mm}$ and 0.34 respectively. These findings indicate that the temperature distribution, especially temperature gradient $(\mathrm{dT} / \mathrm{dx})$ influences the formation of distortion. It can be seen that a low or almost no distortion is observed when the heating temperature of TTT achieves $200{ }^{\circ} \mathrm{C}[6][7][8]$. 


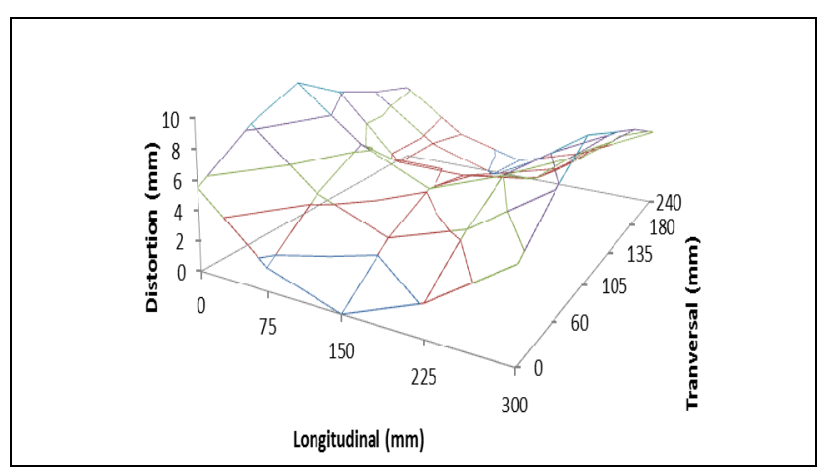

(a). As welded

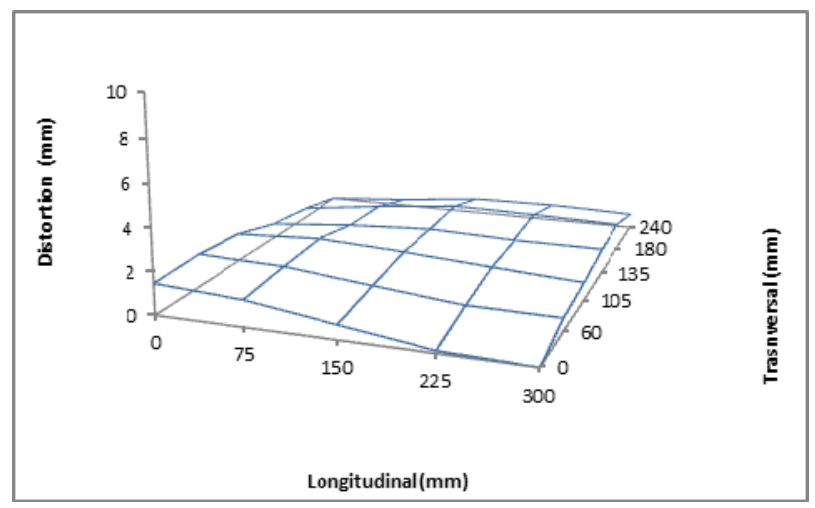

(c). TTT $200^{\circ} \mathrm{C}$

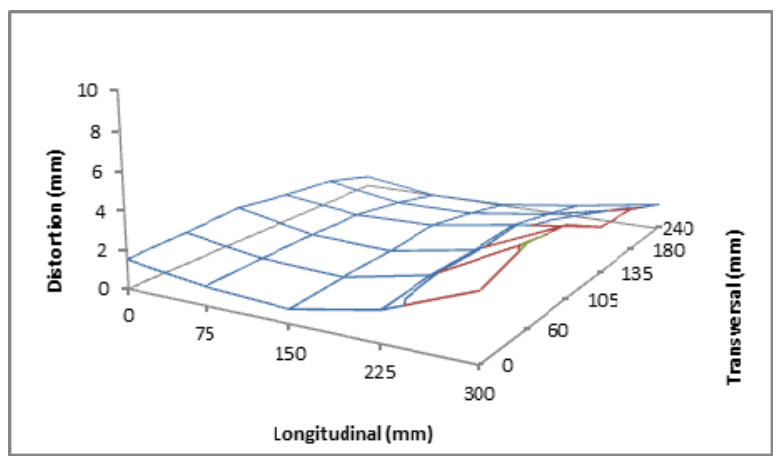

(b). TTT $100{ }^{\circ} \mathrm{C}$

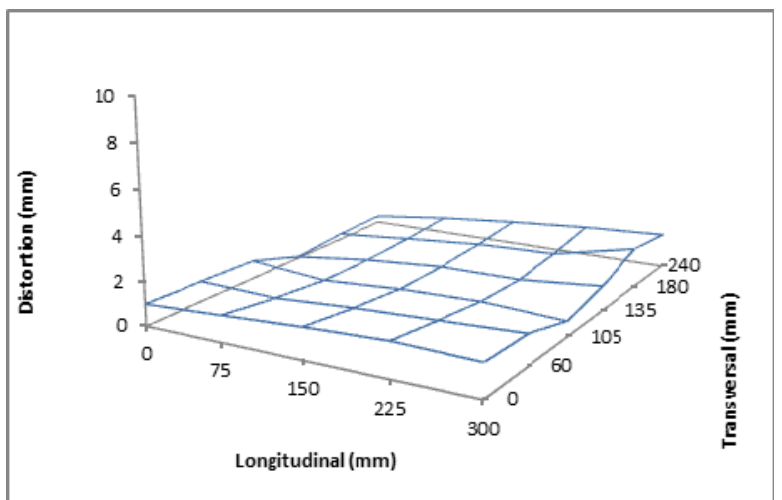

(d). $\operatorname{TTT} 300^{\circ} \mathrm{C}$

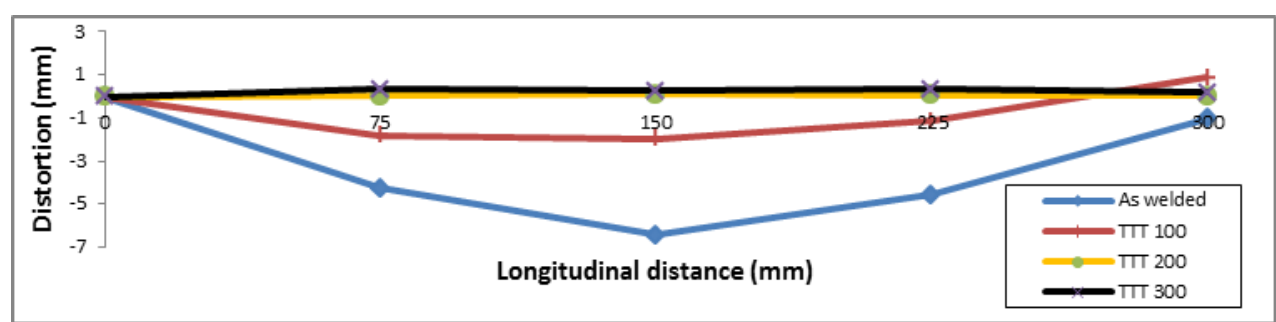

(e)

Fig. 3. Result of distortions, (a), (b), (c), (d), Three-dimension of distortion, (e) longitudinal direction of distortion

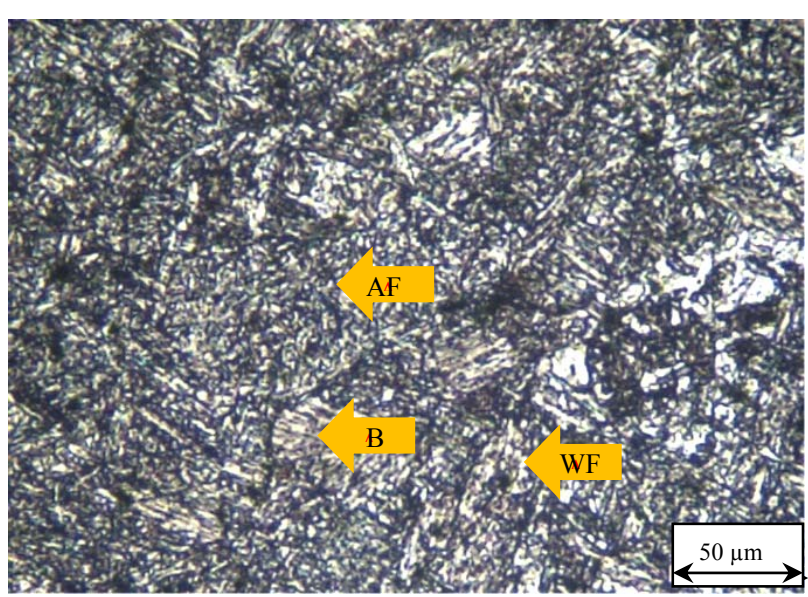

(a). As welded

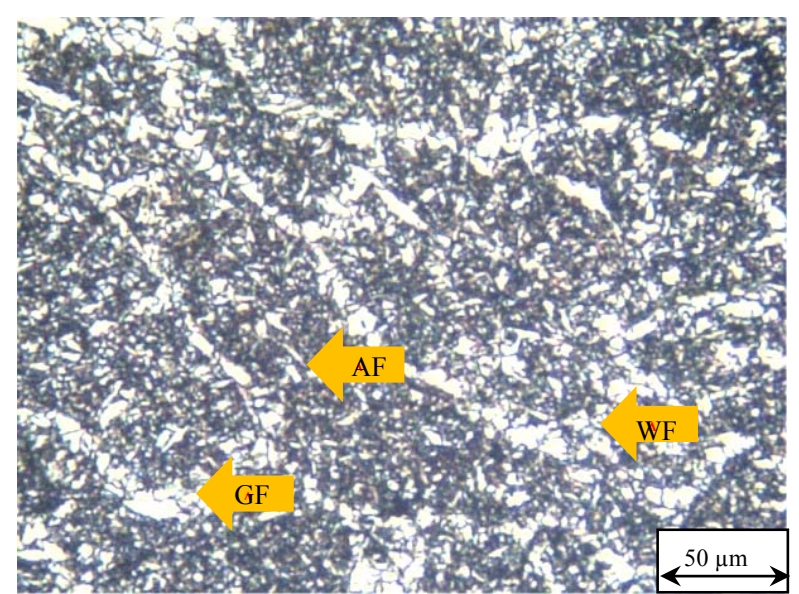

(b). TTT $100{ }^{\circ} \mathrm{C}$ 


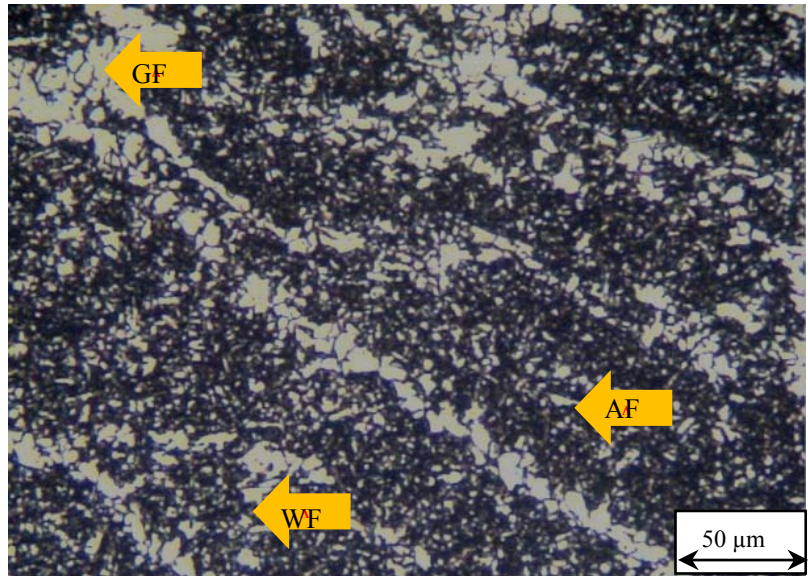

(c). TTT $200{ }^{\circ} \mathrm{C}$

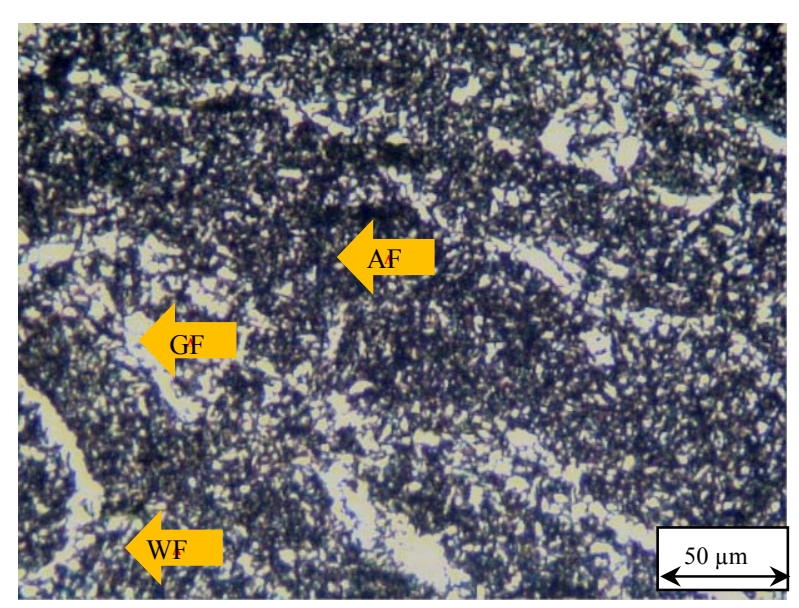

(d). TTT $300{ }^{\circ} \mathrm{C}$

Fig. 4. Microstructures of weld meta

Microstructures of the weld metals with and without TTT treatment are shown in Fig. 4. It can be seen that microstructures of as welded metal consists of mainly bainite. In contrast, a TTT treated weld metals are composed of acicular ferrite (AF) as the major microstructure with a small amount of grain boundary ferrite (GF) and Widmanstaten ferrite (WF). It has been reported that acicular ferrite gives high strength, good impact toughness [16] and fatigue performance [2], due to its fine grained and interlocking structures. In comparison with the as welded weld metal, the amount of acicular ferrite in TTT treated weld metal is higher.

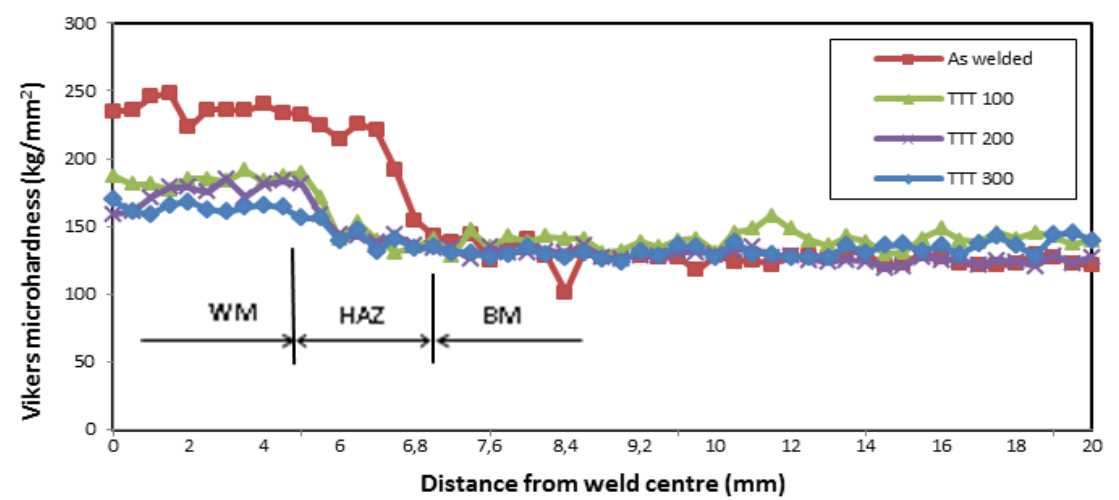

Fig. 5. Result of hardness FCAW weld in A36 Steel with various heating temperature at TTT weld treatment

Fig. 5 shows the distribution of hardness for all of welded joint. Hardness test were conducted in weld metal (WM), coarse HAZ, fine HAZ, base metal (BM). It can be seen that the highest hardness values are observed in as welded weld joint. This is because the weld cooling rate in as welded condition is relatively fast resulting in bainite microstructure. Increasing TTT heating temperature decreases hardness.

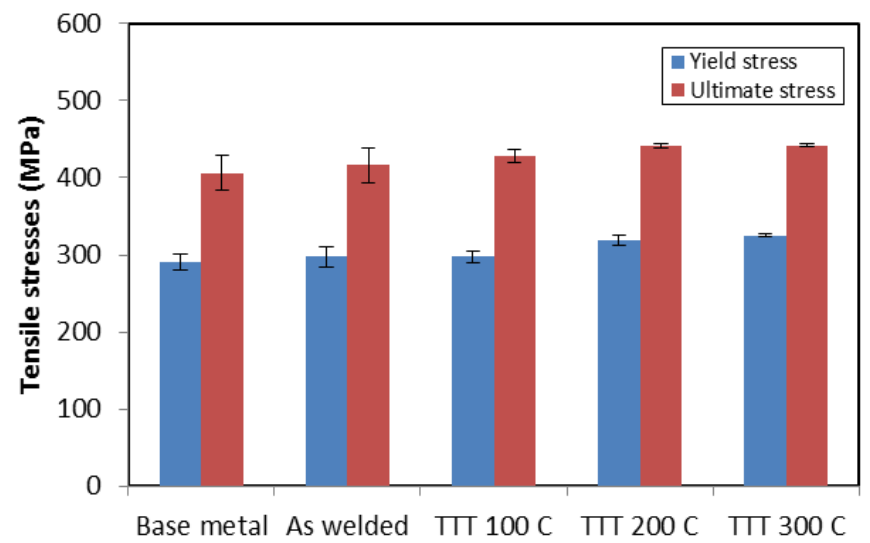

Fig. 6. Result of tensile stress FCAW weld in A36 Steel with various heating temperature at TTT weld treatment 
Results of tensile stress for as welded and TTT-treated welds under various heating temperatures are shown in Fig. 6. As shown in figure, increasing TTT heating temperature increase both yield and tensile strength. These results seem to confirm that cooling rate under TTT treatment plays decisive role in determining weld yield and ultimate strength due to formation of fine-grained acicular ferrite.

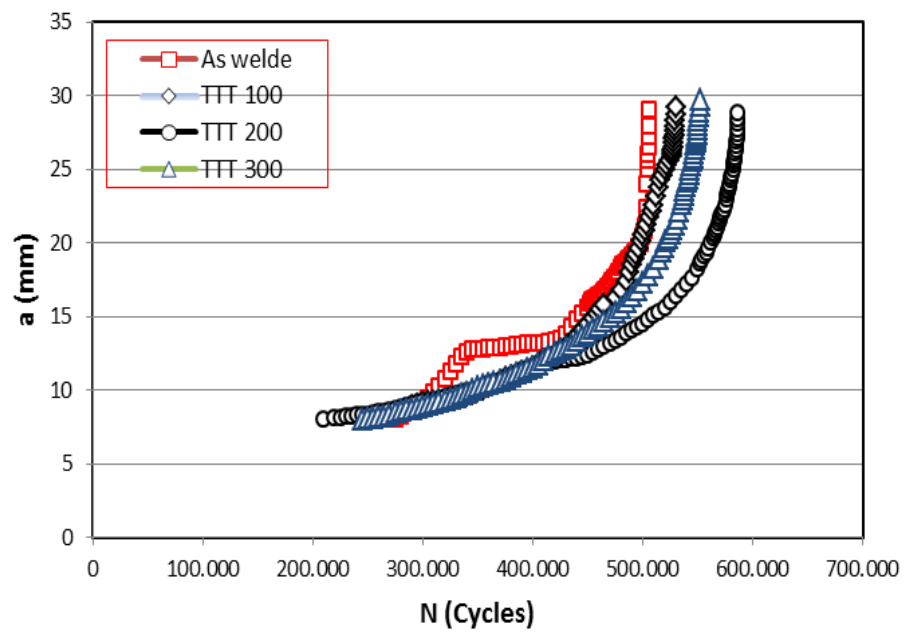

(a)

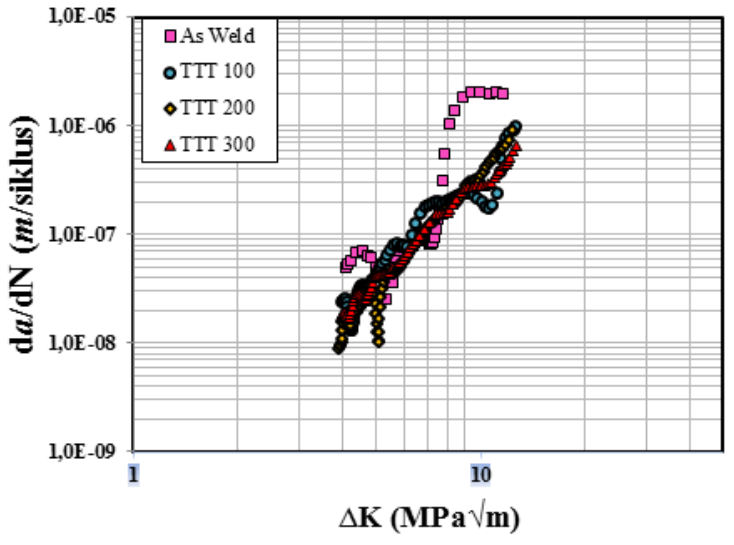

(b)

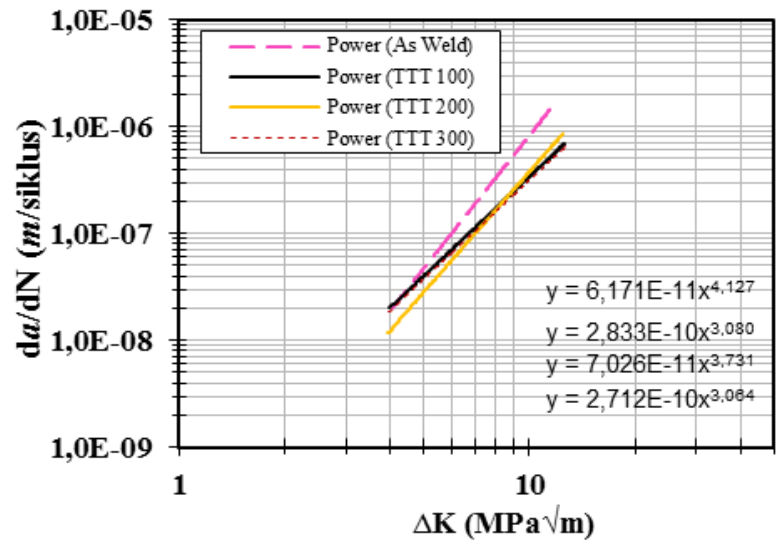

(c)

Fig. 7. (a) Schematic diagram of a-N, (b) Plot of (da/dN)- $\Delta \mathrm{K}$, and (c) Curves trendline of (da/dN)- $\Delta \mathrm{K}$

Fig. 7 shows the results of fatigue test for all weld joints under study presented by plotting crack length (a) as a function of number of cycles (Fig. 7a) and also the relation between propagation rate of fatigue crack (da/dN) and stress intensity factor range $(\Delta \mathrm{K})$ as shown in Fig. $7 \mathrm{~b}$. The trend lines were taken from region II of da/dN $\Delta \mathrm{K}$ curves as shown in Fig. 7c. Figure 7a shows that the fatigue life (given in the number of cycles) of the weld joint under TTT treatment at heating temperature of $200{ }^{\circ} \mathrm{C}$ is the highest. In Fig. $7 \mathrm{~b}-7 \mathrm{c}$ the fatigue crack growth rate is influenced by $\mathrm{C}$ and $\mathrm{n}$ values. Compared with as welded weld joint, fatigue crack propagation of the weld treated using TTT with $200{ }^{\circ} \mathrm{C}$ heating is lower. These results seen to be consistent with previous report [6] $[7][8][11]$.

TABLE 2. Paris constants on each specimen

\begin{tabular}{ccc}
\hline Specimen & C & n \\
\hline As welded & $6,171 \mathrm{E}-11$ & 4,127 \\
TTT $100^{\circ} \mathbf{C}$ & $2,833 \mathrm{E}-10$ & 3,080 \\
TTT $200^{\circ} \mathbf{C}$ & $2.755 \mathrm{E}-11$ & 3,731 \\
TTT $300^{\circ} \mathbf{C}$ & $2,712 \mathrm{E}-10$ & 3,064 \\
\hline
\end{tabular}


The Paris constant of $\mathrm{C}$ and $\mathrm{n}$ can be seen in Table 2. The $\mathrm{n}$ value for the weld treated using TTT heated is smaller than that of as welded, suggesting that fatigue crack growth rate is improved.

Fracture surfaces of weld metals with and without TTT treatment are show in Fig. 8. As shown in this Fig. 8a, fracture surface of as weld metal specimen shows that they have large striations typically around $30 \mu \mathrm{m}$ in which with the crack direction from left to right. On the other hand fracture surface of the weld treated by TTT at heating temperature $200{ }^{\circ} \mathrm{C}$ shows that they have finer striation spacing. It is also looked that fracture spacing was reducing by TTT treatment. This result could be correlates with the value of Paris constant as shown in Table 2.

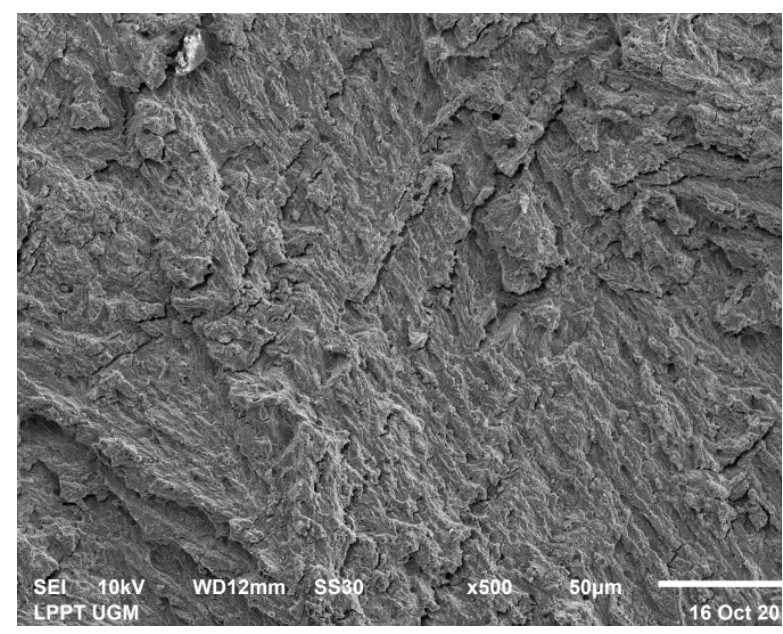

(a)

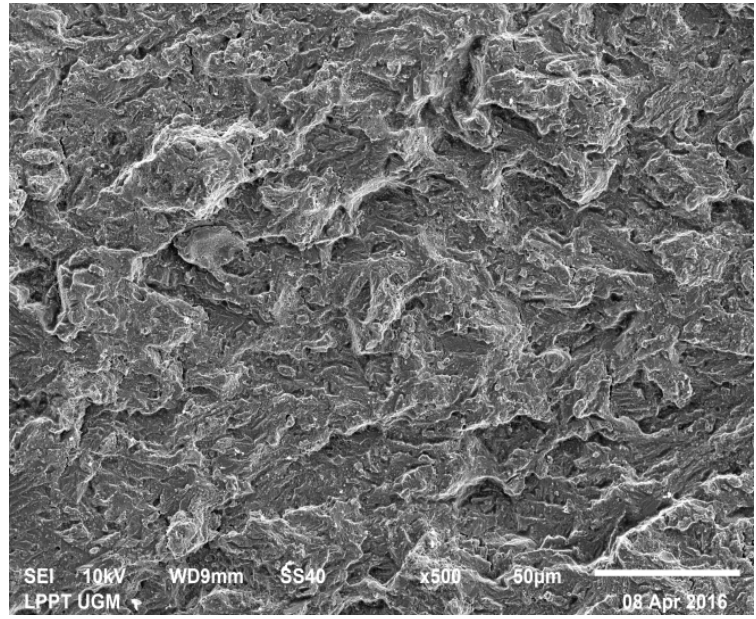

(b)

Fig. 8. Fracture surface, a) As welded, b) welded by temperature $200{ }^{\circ} \mathrm{C}$ TTT weld treatment

\section{IV.CONCLUSION}

The conclusion that can be drawn from this research can be summarized ad follow:

1. The distortion can be reduced by TTT weld treatment

2. Heating at $200{ }^{\circ} \mathrm{C}$ of TTT treatment is the most optimum to reduce distortion

3. The number of acicular ferrite can be improved by TTT weld treatment

4. Both mechanical properties and fatigue life time can be upgraded by TTT weld treatment.

\section{ACKNOWLEDGMENT}

This work was financially supported by BPPS on Minister of Research and High Education of Indonesia. Therefore, the authors are greatly appreciated.

\section{REFERENCES}

[1] P. Michaleris, J. Dantzig, and D. Tortorelli, “Minimization of welding residual stress and distortion in large structures," Weld. J. Res. Suppl., p. 361s-366s, 1999.

[2] S. Ravi, V. Balasubramanian, S. Babu, and S. Nemat Nasser, "Influences of MMR, PWHT and notch location on fatigue life of HSLA steel welds,” Eng. Fail. Anal., vol. 11, no. 4, pp. 619-634, 2004.

[3] M. Mochizuki and M. Toyoda, "Weld Distortion Control During Welding Process With Reverse-Side Heating," J. Eng. Mater. Technol., vol. 129, no. April 2007, pp. 265-270, 2007.

[4] N. Subeki, Jamasri, M. N. Ilman, and P. T. Iswanto, "The Influence of Preheat on Distortion and Fatigue Crack Propagation Rate of FCAW Weld in A 36 Steel Structure,” Appl. Mech. Mater., vol. 842, pp. 83-91, 2016.

[5] Q. Guan, "Control of Buckling Distortions in Plates and Shells," in Processes and Mechanisms of Welding Residual Stress and Distortion, 1 st., Z. Feng, Ed. Cambridge (UK): Woodhead Publishing Ltd, 2005, pp. 295-343.

[6] M. N. Ilman, Kusmono, M. R. Muslih, N. Subeki, and H. Wibowo, "Mitigating distortion and residual stress by static thermal tensioning to improve fatigue crack growth performance of MIG AA5083 welds," Mater. Des., vol. 99, pp. 273-283, 2016.

[7] N. Subeki, Jamasri, M. N. Ilman, and P. T. Iswanto, "The effect of heating temperature in static thermal tensioning (STT) welding on mechanical properties and fatigue crack propagation rate of FCAW in steel A 36," in AIP Conf. Proc., 2017, vol. 030057, p. 030057.

[8] M. N. Ilman, Kusmono, and P. T. Iswanto, "Fatigue crack growth rate behaviour of friction-stir aluminium alloy AA2024-T3 welds under transient thermal tensioning," Mater. Des., vol. 50, pp. 235-243, 2013.

[9] T. D. Huang, R. Dull, C. Conrardy, N. Porter, L. Decan, N. Evans, A. Davis, L. Kvidahl, and P. Keene, "Transient Thermal Tensioning and Prototype System Testing of Thin Steel Ship Panel Structures,” J. Sh. Prod., vol. 24, pp. 1-16, 2008.

[10] P. Michaleris, "Finite element analysis of thermal tensioning techniques mitigating weld buckling distortion," Weld. J., vol. 76, no. November, p. 451, 1997.

[11] Z. Barsoum and I. Barsoum, "Residual stress effects on fatigue life of welded structures using LEFM," Eng. Fail. Anal., vol. 16, no. 1, pp. 449-467, Jan. 2009.

[12] C. Conrardy, T.D. Huang, D. Harwig, P. Dong, L. Kvidahl, N. Evans, and A.Treaster, "Practical Welding Tecnichues to Minimize Distortion in Lighweight Ship Strctures," vol. 22, pp. 239-247, 2006.

[13] P. Michaleris, Ed., "Minimization of Welding Distortion and Buckling-Modeling and Implementation," Cambridge: Woodhead Publishing Ltd, 2011. 
[14] S. Surian, N. M. Rissone Ramini De, H. G. Svoboda, R. Rep, and L. a D. E. Vedia, "Ferritic Deposits : The Challenge Is Tensile Properties," vol. 89, no. March, pp. 54-65, 2010.

[15] J. Song, J. Peters, A. Noor, and P. Michaleris, "Sensitivity Analysis of The Thermomechanical Response of Welding Joints," Solid Struct., vol. 40, pp. 4167-4180, 2003.

[16] M. N. Ilman, R. C. Cochrane, and G. M. Evans, "The development of acicular ferrite in reheated Ti-B-Al-N-type steel weld metals containing various levels of aluminium and nitrogen," Weld. World, vol. 59, no. 4, pp. 565-575, 2015.

\section{AUTHOR PROFILE}

Nur Subeki completed his Masters from Mechanical and Industrial Engineering Department of University of Gadjah Mada. He has compiled his thesis based on the above project work. He is currently (2017) pursuing Ph.D in University of Gadjah Mada.

Jamasri is a Professor in the department of Mechanical and Industrial Engineering of University of Gadjah Mada. He did his Ph.D from Strathclyde University, United Kingdom in 1993.

Mochammad Noer Ilman is a Professor in the department of Mechanical and Industrial Engineering of University of Gadjah Mada. He did his Ph.D from Leeds University, United Kingdom in 2001.

Priyo Tri Iswanto is a Lecturer in the department of Mechanical and Industrial Engineering of University of Gadjah Mada. He did his Dr. Eng from Saga University, Japan in 2006. 